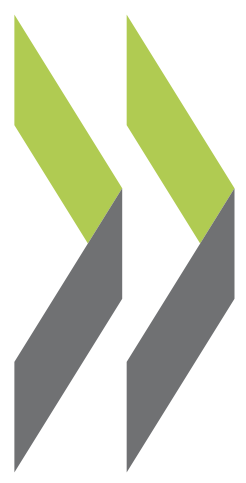

SIGMA Papers No. 28

\title{
A Comparison on the EC Procurement Directives and the UNCITRAL Model OECD 


\section{Unclassified}

Organisation de Coopération et de Développement Economiques

Organisation for Economic Co-operation and Development
CCNM/SIGMA/PUMA(2000)32

OLIS : 25-Oct-2000

Dist. : 26-Oct-2000

SIGMA -- A JOINT INITIATIVE OF THE OECD AND THE EUROPEAN UNION,

Or. Eng.

PRINCIPALLY FINANCED BY THE EUROPEAN UNION'S PHARE PROGRAMME

\section{A COMPARISON OF THE EC PROCUREMENT DIRECTIVES AND}

THE UNCITRAL MODEL LAW 


\section{THE SIGMA PROGRAMME}

SIGMA - Support for Improvement in Governance and Management in Central and Eastern European Countries is a joint initiative of the OECD and the European Union. The initiative supports public administration reform efforts in thirteen countries in transition, and is principally financed by the European Union's Phare Programme.

The Organisation for Economic Co-operation and Development is an intergovernmental organisation of 29 democracies with advanced market economies. Its Centre for Co-operation with Non-Members channels the Organisation's advice and assistance over a wide range of economic issues to reforming countries in Central and Eastern Europe and the former Soviet Union. Phare provides grant financing to support its partner countries in Central and Eastern Europe to the stage where they are ready to assume the obligations of membership of the European Union.

Phare and SIGMA serve the same countries: Albania, Bosnia-Herzegovina, Bulgaria, the Czech Republic, Estonia, the former Yugoslav Republic of Macedonia, Hungary, Latvia, Lithuania, Poland, Romania, Slovakia and Slovenia.

Established in 1992, SIGMA works within the OECD's Public Management Directorate, which provides information and expert analysis on public management to policy-makers and facilitates contact and exchange of experience amongst public sector managers. SIGMA offers beneficiary countries access to a network of experienced public administrators, comparative information, and technical knowledge connected with the Public Management Directorate.

SIGMA aims to:

- assist beneficiary countries in their search for good governance to improve administrative efficiency and promote adherence of public sector staff to democratic values, ethics and respect of the rule of law;

- help build up indigenous capacities at the central governmental level to face the challenges of internationalisation and of European Union integration plans; and

- $\quad$ support initiatives of the European Union and other donors to assist beneficiary countries in public administration reform and contribute to co-ordination of donor activities.

Throughout its work, the initiative places a high priority on facilitating co-operation among governments. This practice includes providing logistical support to the formation of networks of public administration practitioners in Central and Eastern Europe, and between these practitioners and their counterparts in other democracies.

SIGMA works in five technical areas: Public Administration Development Strategies; Policy-Making, Co-ordination and Regulation; Budgeting and Resource Allocation; Public Service Management; and Audit and Financial Control. In addition, an Information Services Unit disseminates published and on-line materials on public management topics.

\section{Copyright OECD, 2000}

Applications for permission to reproduce or translate all or part of this material should be made to: Head of Publications Service, OECD, 2 rue André-Pascal, 75775 Paris Cedex 16, France.

Views expressed in this publication do not necessarily represent official views of the Commission, OECD Member countries, or the central and eastern European countries participating in the Programme. 


\title{
FOREWORD
}

This chart compares the EC Procurement Directives and the UNCITRAL Model Law on Procurement. Most central and eastern European countries used the Model Law as the basis of their public procurement laws in the early 1990s. Now that many countries of the region are candidates for EU accession, they must adapt their laws to the EC Directives. ${ }^{1}$

The chart highlights important differences and similarities in key areas dealt with by the EC Directives and the Model Law. It does not purport to provide an exhaustive comparison of all provisions. For a more detailed and legally precise analysis, those interested should refer to the EC legislation and the UNCITRAL Model Law themselves, as well as to legal commentaries.

Cynthia Walker, SIGMA, and Carmen Apostol, Director General, General Directorate for Regulation and Monitoring of Public Procurement, Ministry of Finance, Romania, developed the concept of the chart. Sue Arrowsmith, Professor of Law, Nottingham University, United Kingdom, designed the chart and wrote the contents.

For further information, please contact Piotr-Nils Gorecki, SIGMA Administrator for Public Procurement, at the address below.

This, and other SIGMA Papers are available on the SIGMA website at: www.oecd.org/puma/sigmaweb

This paper is published on the responsibility of the Secretary-General of the OECD.

\author{
SIGMA-OECD, 2 rue André-Pascal, 75775 Paris, Cedex 16, France \\ Tel. (33.1) 45.24.79.33; Fax: (33.1) 45.24.13.00 \\ e-mail: sigma.contact@ oecd.org
}

1. On 10 May 2000, the European Commission adopted a legislative package to simplify and modernise the Procurement Directives. The draft legislative proposals are now going through the various stages within the European Parliament and the European Council. This is a lengthy process and may result in amendments being made to the Commission's text. In the interim, candidate countries for European Union membership are advised by the Commission to continue transposing the existing Directives into their national law. For more information, see EC press release number IP/00/461, available on the Internet at: http://simap.eu.int. 


\section{EXECUTIVE SUMMARY}

This chart compares the EC Procurement Directives ${ }^{2}$ and the UNCITRAL Model Law on Procurement of Goods, Construction and Services ${ }^{3}$. Most central and eastern European countries used the Model Law as the basis of their public procurement laws in the early 1990s. Now that many countries of the region are candidates for EU accession, they must adapt their laws to EC Directives. The aim of the chart is to assist in that process.

The EC Procurement Directives were introduced into the European Union to further the EU's policy of enabling enterprises from all EU states to compete fairly in public procurement markets. The most important objective of this policy is to prevent discrimination by procuring entities in favour of their own national enterprises. The EC Directives support this by, inter alia, requiring major contracts to be advertised, open to competition, and awarded through transparent procedures. These conditions make it difficult to disguise discrimination.

The UNCITRAL Model Law on Procurement of Goods, Construction and Services sets out procedures for the award of public contracts. It is designed for the use of countries introducing procurement laws, or reforming their procurement systems, with the aims of achieving economy and efficiency in public procurement and reducing corruption. The Model Law also seeks to promote international competition in public procurement markets. States should in general seek these objectives by advertising and holding a competition for procurements, and awarding contracts through transparent procedures.

This chart highlights similarities and differences of the two regimes in the following main areas:

- Coverage of the regimes;

- Methods of procurement;

- Contract award procedures;

- Post-award obligations (such as award notices and record keeping); and

- Remedies for providers.

The rules found in the EC Directives and the UNCITRAL Model Law are similar in many respects. For example, both:

- Provide for procedures for major contracts that involve advertisement and a competition;

- Provide for exceptions from competition for circumstances such as urgency or national security;

2. The Procurement Directives applicable to the European Member States referred to in this chart are Council Directive 92/50/EEC of 18 June 1992 relating to the coordination of procedures for the award of public service contracts; Council Directive 93/36/EEC of 14 June 1993 coordinating procedures for the award of public supply contracts; Council Directive 93/37/EEC of 14 June 1993 concerning the coordination of procedures for the award of public works contracts; and Council Directive 93/38/EEC of 14 June 1993 co-ordinating the procurement procedures of entities operating in the water, energy, transport and telecommunications sectors. For further information, refer to the European Union's Eur-Lex website at http://europa.eu.int/eur-lex/index.html.

3. The UNCITRAL Model Law on Procurement of Goods, Construction and Services with Guide to Enactment (1994) can be referred to on the UNCITRAL website at http://www.uncitral.org. 
- Require the use of commercial award criteria that are stated to bidders in advance; and

- Require bidders to be given reasons for decisions on request for most procurements.

However, there are also a number of differences, some significant and some of detail. In some respects, the EC Directives apply stricter rules than the Model Law on the same issue (e.g., use of flexible procedures in goods and construction procurement); in others, they are less strict (e.g., use of restricted tendering). The EC Directives also cover a few matters not dealt with in the Model Law (e.g., collecting statistics); whilst the Model Law covers many issues not addressed at all in the EC Directives (e.g., tender securities, opening of bids). These differences arise for a number of reasons, including:

- Different objectives and emphasis of the two regimes. For example, because it is directed at eliminating discrimination, the EC regime does not allow room for national preferences. However, the UNCITRAL Model includes provision for using these provided that this is done in a transparent manner, in recognition of the fact that, whilst preferences are to be discouraged, they will in reality be used by states drawing on the Model Law. Similarly, the EC Directives apply only to the largest contracts because they are only concerned with contracts of interest to international trade, whilst the Model Law applies more widely.

- Different views on the balance between transparency and other policies. For example, the EC rules allow a free choice between open and restricted tendering, whilst the Model Law prefers an open form of tendering except where specific grounds exist to depart from this. However, the Model Law provides for more flexibility than the EC rules in using forms of procedure other than tendering in the case of goods and construction. 


\section{CCNM/SIGMA/PUMA(2000)32}

\section{Comparison between the EC Procurement Directives and the UNCITRAL Model Law ${ }^{4}$}

N.B. This document does not aim to provide an exhaustive comparison of all issues dealt with by the EC Directives and Model Law, or to give a full account of all their provisions; rather, it highlights some important differences and similarities in key areas. For a more detailed and legally precise analysis, interested parties should refer to the EC legislation and Model Law themselves, and to legal commentaries.

\begin{tabular}{|c|c|c|c|}
\hline & EC Directives 92/50, 93/36 and 93/37 & EC Directive 93/38 & UNCITRAL Model Law \\
\hline $\begin{array}{l}\text { Procuring entities } \\
\text { covered }\end{array}$ & 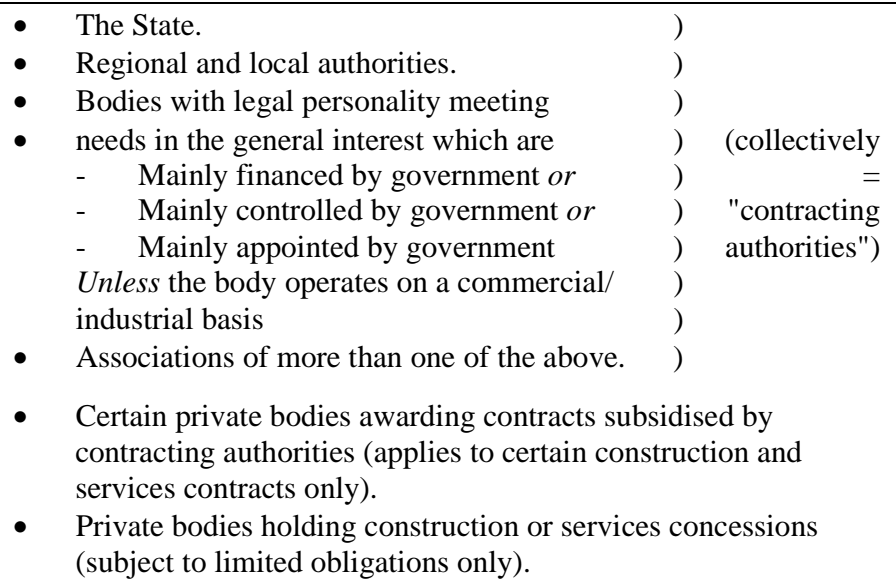 & $\begin{array}{l}\text { - Entities which are "contracting authorities" } \\
\text { under the other directives (see previous } \\
\text { column). } \\
\text { Entities subject to the dominant influence of } \\
\text { a contracting authority (e.g. state controlled } \\
\text { companies). } \\
\text { - Entities with special or exclusive rights } \\
\text { (including private entities with such rights). }\end{array}$ & $\begin{array}{l}\text { (For states in which the federal/central } \\
\text { government regulates all procurement.) Any } \\
\text { government department, agency, organ or } \\
\text { other unit, or any sub-division thereof } \\
\text { (except those expressly excluded), } \\
\text { or } \\
\text { (For states in which procurement at } \\
\text { sub-federal level is not federally regulated.) } \\
\text { Any department, agency, organ or other unit, } \\
\text { or any sub-division thereof of the national } \\
\text { government (except those expressly } \\
\text { excluded). } \\
\text { Any other entity specifically included by the } \\
\text { regulating government. }\end{array}$ \\
\hline $\begin{array}{l}\text { Types of contract } \\
\text { covered }\end{array}$ & $\begin{array}{l}\text { Contracts in writing for pecuniary interest for the procurement for } \\
\text { goods, construction or services, } \\
\text { except for } \\
\text { those made in connection with activities covered by directive 93/38. }\end{array}$ & $\begin{array}{l}\text { Contracts in writing for pecuniary interest for the } \\
\text { procurement of goods, construction or services, } \\
\text { which are made in connection with certain } \\
\text { activities in the sectors of water, energy, } \\
\text { transport, and telecommunications. }\end{array}$ & $\begin{array}{l}\text { Contracts for the procurement of goods, } \\
\text { construction and services. }\end{array}$ \\
\hline
\end{tabular}

4. The Procurement Directives applicable to the European Union Member States referred to in this chart are Council Directive 92/50/EEC of 18 June 1992 relating to the coordination of procedures for the award of public service contracts; Council Directive 93/36/EEC of 14 June 1993 coordinating procedures for the award of public supply contracts; Council Directive 93/37/EEC of 14 June 1993 concerning the coordination of procedures for the award of public works contracts; and Council Directive 93/38/EEC of 14 June 1993 co-ordinating the procurement procedures of entities operating in the water, energy, transport and telecommunications sectors. For further information, refer to the European Union's Eur-Lex website at http://europa.eu.int/eur-lex/index.html. The UNCITRAL Model Law on Procurement of Goods, Construction and Services with Guide to Enactment (1994) can be referred to on the UNCITRAL website at http://www.uncitral.org. 


\begin{tabular}{|c|c|c|c|}
\hline & \multirow[b]{2}{*}{ EC Directives 92/50, 93/36 and 93/37 } & \\
\hline & & EC Directive 93/38 & UNCITRAL Model Law \\
\hline Thresholds & 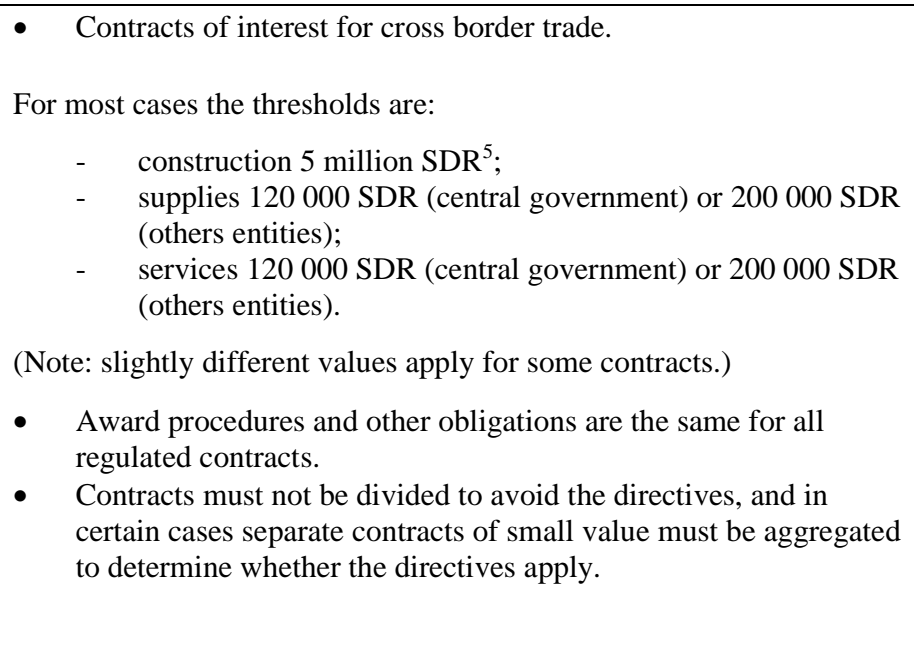 & $\begin{array}{l}\text { Contracts considered of interest for cross } \\
\text { border trade. } \\
\text { For most cases the thresholds are: } \\
\text { - } \quad \text { construction } 5 \text { million SDR; } \\
\text { - } \quad \text { supplies } 400000 \text { SDR ( } 600000 \mathrm{SDR} \\
\quad \text { for telecommunications entities); } \\
\text { - } \quad \text { services } 400000 \text { SDR ( } 600 \text { 000 SDR } \\
\text { for telecommunications entities). } \\
\text { (Note: slightly different values apply for some } \\
\text { contracts.) } \\
\text { Award procedures and other obligations are } \\
\text { the same for all regulated contracts. } \\
\text { Contracts must not be divided to avoid the } \\
\text { directives, and in certain cases separate } \\
\text { contracts of small value must be aggregated } \\
\text { to determine whether the directives apply. }\end{array}$ & $\begin{array}{l}\text { - Contracts large enough to justify some form } \\
\text { of competition, as determined by the } \\
\text { regulating state. } \\
\text { - Award procedures and other obligations } \\
\text { differ according the size of the contract. } \\
\text { - Contracts must not be divided to avoid } \\
\text { applying relevant procedures. }\end{array}$ \\
\hline Exclusions & $\begin{array}{l}\text { - "Hard" defence equipment and related construction and services. } \\
\text { - Certain other contracts affected by secrecy or security (under } \\
\text { certain conditions). } \\
\text { - Contracts awarded pursuant to: } \\
\text { - certain international agreements with countries not subject to } \\
\text { the directives; } \\
\text { - } \quad \text { international agreements for the stationing of troops. } \\
\text { - } \text { ontracts awarded pursuant to the procedures of an international (e.g. World Bank). } \\
\text { - Services concession contracts. } \\
\text { - } \text { hervices contracts awarded to other contracting authorities which } \\
\text { Contracts for: certain broadcasting services; certain } \\
\text { telecommunications services; arbitration and conciliation services; } \\
\text { certain financial services; certain research and development } \\
\text { services. } \\
\text { Note also that construction concessions and contracts for some kinds of } \\
\text { services ("non-priority" services) are subject to only very limited }\end{array}$ & $\begin{array}{l}\text { Same exclusions apply with the other directives } \\
\text { (see previous column), plus: } \\
\text { - Services contracts awarded to affiliated } \\
\text { companies and joint venture partners, under } \\
\text { certain conditions. } \\
\text { - Contracts awarded for the purposes of resale } \\
\text { or hire, where the activity is carried out in a } \\
\text { competitive market. } \\
\text { Contracts connected with bus transport and } \\
\text { telecommunications activities, when the } \\
\text { procuring entity operates in a competitive } \\
\text { market. } \\
\text { Contracts connected with the upstream oil } \\
\text { and gas sector, where: } \\
\text { - } \quad \text { the procuring entity competes for } \\
\text { licences under a transparent system; } \\
\text { exemption has been given by the } \\
\text { Commission; }\end{array}$ & $\begin{array}{l}\text { - All procurement involving national defence } \\
\text { and security except to the extent that the } \\
\text { application of the law is specifically } \\
\text { declared to participants. } \\
\text { Contracts affected by an agreement with } \\
\text { another state or an international financing } \\
\text { institution (e.g. the World Bank), to the } \\
\text { extent that the law conflicts with the terms } \\
\text { of the agreement. } \\
\text { Other procurement which the state chooses } \\
\text { to exclude by law or regulation. }\end{array}$ \\
\hline
\end{tabular}

5. SDR stands for Special Drawing Rights. It is an international reserve asset and a unit of account. 
CCNM/SIGMA/PUMA(2000)32

\begin{tabular}{|c|c|c|c|}
\hline & EC Directives 92/50, 93/36 and 93/37 & EC Directive 93/38 & UNCITRAL Model Law \\
\hline & provisions, which do not require a competition. & $\begin{array}{l}\text { - the procuring entity follows principles } \\
\text { of competition and non-discrimination. }\end{array}$ & \\
\hline $\begin{array}{l}\text { Provisions favouring } \\
\text { domestic } \\
\text { providers/products } \\
\text { etc. }\end{array}$ & $\begin{array}{l}\text { Generally prohibited under the EU Treaties and the directives } \\
\text { (although subject to exceptions e.g. military equipment). }\end{array}$ & $\begin{array}{l}\text { Generally prohibited under the EU Treaties } \\
\text { (although subject to exceptions e.g. military } \\
\text { equipment). }\end{array}$ & $\begin{array}{l}\text { Contracts can be restricted to national } \\
\text { firms/products etc. and preferences can be given } \\
\text { to national firms in evaluating bids where } \\
\text { permitted by law, subject to rules on } \\
\text { transparency. }\end{array}$ \\
\hline $\begin{array}{l}\text { The "usual" award } \\
\text { procedure }\end{array}$ & $\begin{array}{l}\text { Entities may choose freely between an open (tendering) procedure or } \\
\text { restricted (tendering) procedure. }\end{array}$ & $\begin{array}{l}\text { Entities may choose freely between an open } \\
\text { procedure, restricted procedure, or negotiated } \\
\text { procedure with a call for competition. }{ }^{6} \text {. }\end{array}$ & 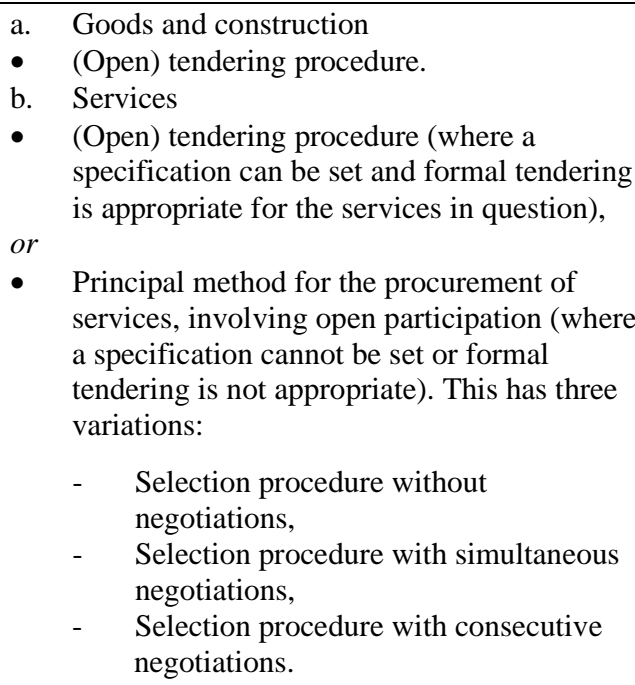 \\
\hline $\begin{array}{l}\text { Competitive award } \\
\text { procedures which are } \\
\text { available in limited } \\
\text { circumstances only }\end{array}$ & Competitive form of the negotiated procedure? & $\begin{array}{l}\text { Not applicable since all competitive procedures } \\
\text { freely available. }\end{array}$ & $\begin{array}{ll}\text { a. } & \text { Goods and construction } \\
\text { - } & \text { Restricted tendering. } \\
\text { - } & \text { Two-stage tendering. } \\
\text { - } & \text { Request for proposals. } \\
\text { - } & \text { Competitive negotiations. } \\
\text { - } & \text { Request for quotations. }\end{array}$ \\
\hline
\end{tabular}

6. Of the UNCITRAL procedures, this procedure is closest to competitive negotiations. However, a more structured approach than is actually required (similar to the UNCITRAL request for proposals or two stage tendering) can be applied within the framework of the negotiated procedure with a competition, and many entities choose such a structured approach when the negotiated procedure with competition is available under the directives.

7. See footnote 5 . 
CCNM/SIGMA/PUMA(2000)32

\begin{tabular}{|c|c|c|c|}
\hline & & & \\
\hline & EC Directives $92 / 50,93 / 36$ and $93 / 37$ & EC Directive 93/38 & UNCITRAL Model Law \\
\hline & & & $\begin{array}{l}\text { b. } \\
\text { Services } \\
\text { abe methods as for goods and construction (see } \\
\text { above) plus: } \\
\text { - Principal method for procurement of } \\
\text { services, with direct solicitation. This has } \\
\text { three variations: } \\
\text { - } \\
\text { Selection procedure without } \\
\text { negotiations, } \\
\text { - Selection procedure with simultaneous } \\
\text { negotiations, } \\
\text { - Selection procedure with consecutive } \\
\text { negotiations. }\end{array}$ \\
\hline $\begin{array}{l}\text { Grounds for using } \\
\text { competitive award } \\
\text { procedures under than } \\
\text { open tendering/open } \\
\text { solicitation of } \\
\text { proposals }\end{array}$ & $\begin{array}{l}\text { Free access to restricted procedure; and negotiated procedure with } \\
\text { competition available on the following grounds: } \\
\text { - Specification cannot be set (services only); } \\
\text { - } \quad \text { overall pricing not possible (construction and services only); } \\
\text { - contracts for development of prototype construction and } \\
\text { - } \\
\text { services } ; \\
\text { failure of previous open or restricted procedures, where } \\
\text { negotiations are conducted with all qualified bidders who } \\
\text { participated in those procedures. }\end{array}$ & $\begin{array}{l}\text { - Free access to all competitive forms of } \\
\text { procedure. }\end{array}$ & $\begin{array}{l}\text { a. Goods and construction } \\
\text { - } \quad \text { Limited number of providers due to highly } \\
\text { complex or specialised nature of } \\
\text { requirement (restricted tendering). } \\
\text { - } \quad \text { Time and cost of evaluation would be } \\
\text { disproportionate under other methods } \\
\text { (restricted tendering). } \\
\text { Detailed specification of requirement not } \\
\text { feasible and either the procuring entity needs } \\
\text { offers on how to meet its requirements } \text { or } \\
\text { negotiations are necessary because of the } \\
\text { technical nature of the requirement (two } \\
\text { stage tendering, request for proposals or } \\
\text { competitive negotiation). } \\
\text { Development of prototype products, } \\
\text { construction or services (two stage } \\
\text { tendering, request for proposals or } \\
\text { competitive negotiation). } \\
\text { - National defence and security (where not } \\
\text { excluded from the Law altogether). } \\
\text { Failure of previous open tendering } \\
\text { procedures, and new open tendering } \\
\text { procedures would be unlikely to produce a } \\
\text { contract (two stage tendering, request for }\end{array}$ \\
\hline
\end{tabular}

8. Note that for supplies a negotiated procedure without competition may be used for development of prototypes. 


\begin{tabular}{|c|c|c|c|}
\hline & EC Directives 92/50, 93/36 and 93/37 & EC Directive 93/38 & UNCITRAL Model Law \\
\hline & & & $\begin{array}{l}\text { proposals or competitive negotiation). } \\
\text { Tendering impractical for reasons of } \\
\text { urgency not foreseeable or due to dilatory } \\
\text { conduct by the procuring entity (competitive } \\
\text { negotiations). } \\
\text { Other procedures are impractical for reasons } \\
\text { of urgency due to a catastrophic event } \\
\text { (competitive negotiations). } \\
\text { b. Services } \\
\text { - Where specification can be set and tendering } \\
\text { is appropriate, procedures other than open } \\
\text { tendering are available in same } \\
\text { circumstances as for goods and construction } \\
\text { (see a. above). } \\
\text { For other cases, principal method for } \\
\text { procurement of services available in direct } \\
\text { rather than open form on the grounds: } \\
\text { - } \quad \text { services available only from a limited } \\
\text { - number of providers; } \\
\text { time and cost of evaluation would be } \\
\text { - disproportionate under open method; } \\
\text { - confidentiality; }\end{array}$ \\
\hline $\begin{array}{l}\text { Grounds for using } \\
\text { non-competitive } \\
\text { procedures (single } \\
\text { source procurement) }\end{array}$ & $\begin{array}{l}\text { - Contracts for manufacture of prototype products. } \\
\text { Where there is only possible provider for technical or artistic } \\
\text { reasons or because of exclusive rights. } \\
\text { Where strictly necessary for reasons of extreme urgency not } \\
\text { brought about by or attributable to the procuring entity. } \\
\text { Contracts (generally for } 3 \text { years only) for replacement or } \\
\text { additional supplies where the same supplier must be used to avoid } \\
\text { incompatibility or disproportionate technical difficulties. } \\
\text { Contracts to purchase from a previous provider necessary } \\
\text { additional construction or services which were unforeseen when } \\
\text { the original contract was let, where the construction cannot be } \\
\text { separated without great inconvenience or are necessary to } \\
\text { completion of the original contract. (Value of new contract must } \\
\text { be limited to 50\% of original.) } \\
\text { Contracts to purchase from a previous provider construction or }\end{array}$ & $\begin{array}{l}\text { Similar grounds to those under the directives (see } \\
\text { previous column) (although with slight } \\
\text { differences) plus: } \\
\text { - Contracts for development of prototype } \\
\text { services and construction. } \\
\text { - Contracts for supplies purchased on a } \\
\text { commodity market. } \\
\text { - Contracts to make purchases at considerably } \\
\text { below market price under an opportunity } \\
\text { available only for a very short time. } \\
\text { Contracts to purchase goods under } \\
\text { particularly advantageous conditions from a } \\
\text { liquidator or similar. }\end{array}$ & $\begin{array}{l}\text { - Contracts for development of prototype } \\
\text { products, construction or services. } \\
\text { Where there is only possible provider } \\
\text { because of exclusive rights or other } \\
\text { (unspecified) reasons. } \\
\text { - Where other procedures are impractical for } \\
\text { reasons of urgency not foreseeable or due to } \\
\text { dilatory conduct by the procuring entity. } \\
\text { Where other procedures are impractical for } \\
\text { reasons of urgency due to a catastrophic } \\
\text { event. } \\
\text { Contracts for replacement or additional } \\
\text { supplies or services where the same provider } \\
\text { must be used to avoid incompatibility or to } \\
\text { achieve standardisation. }\end{array}$ \\
\hline
\end{tabular}


CCNM/SIGMA/PUMA(2000)32

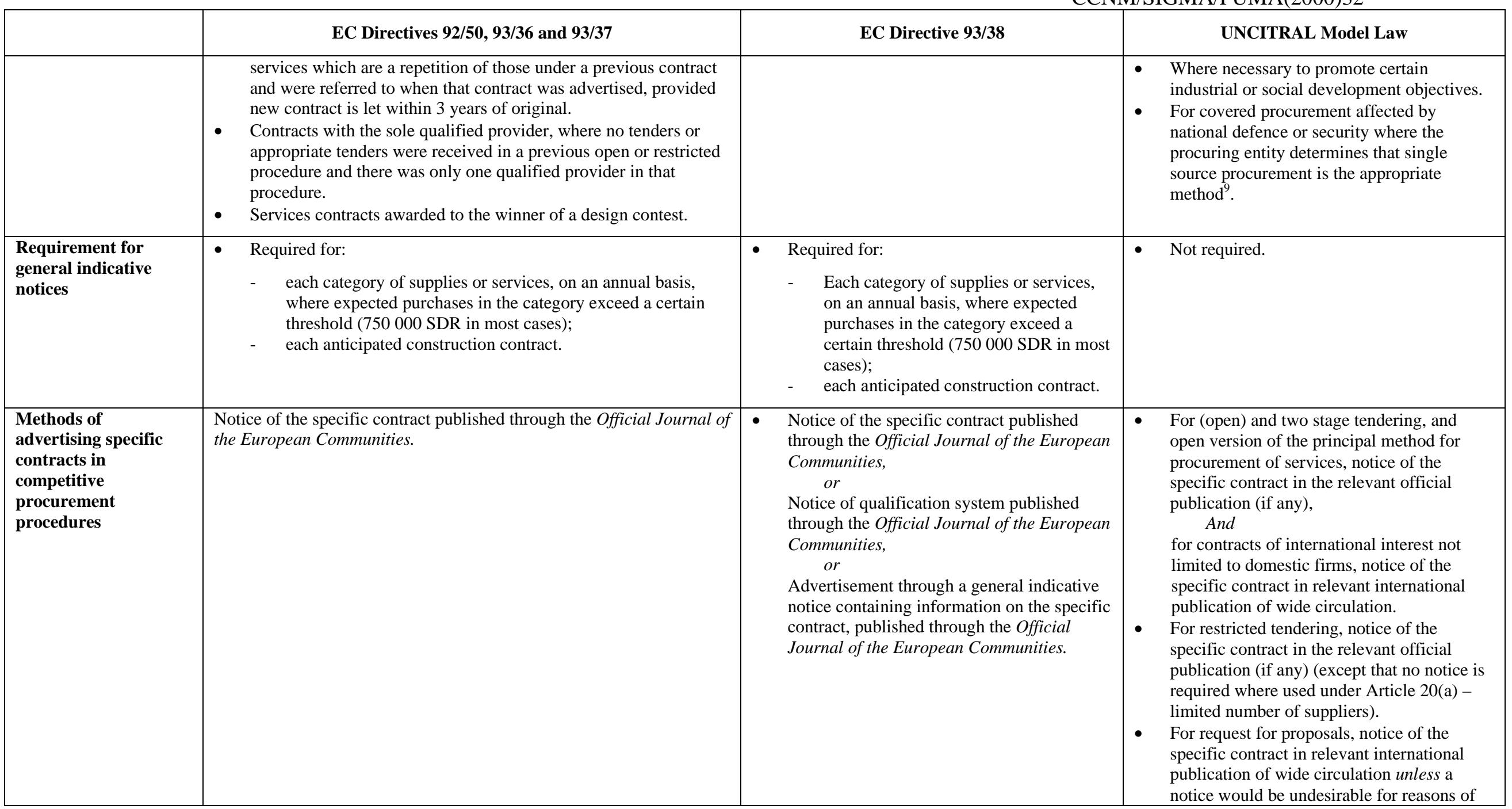

9. Single source procurement is in practice often available under the directives in the same circumstances, since such procurement is often excluded from the directives altogether: see "Exclusions" above. 


\begin{tabular}{|c|c|c|c|}
\hline & EC Directives 92/50, 93/36 and 93/37 & EC Directive 93/38 & UNCITRAL Model Law \\
\hline & & & $\begin{array}{l}\text { economy or efficiency. } \\
\text { For competitive negotiations, request for } \\
\text { quotations, and direct solicitation version of } \\
\text { the principal method for the procurement of } \\
\text { services, no advertisement required. }\end{array}$ \\
\hline $\begin{array}{l}\text { Languages for } \\
\text { advertisements }\end{array}$ & $\begin{array}{l}\text { - For Official Journal notices, main information is published by } \\
\text { Official Journal in all official EU languages. }\end{array}$ & $\begin{array}{l}\text { - For Official Journal notices, main } \\
\text { information is published by Official Journal } \\
\text { in all official EU languages. }\end{array}$ & $\begin{array}{l}\text { For contracts of international interest subject to } \\
\text { open or two stage tendering, or the open version } \\
\text { of the principal method for procurement of } \\
\text { services, which are not limited to domestic firms, } \\
\text { the international notice must be published in a } \\
\text { language customarily used in international trade. } \\
\text { No language requirements apply for other } \\
\text { procedures. }\end{array}$ \\
\hline $\begin{array}{l}\text { Grounds, evidence and } \\
\text { procedure for } \\
\text { exclusion }\end{array}$ & $\begin{array}{l}\text { Exclusion is permitted by the procuring entity only on grounds of: } \\
\text { - lack of technical standing to perform the contract; } \\
\text { - } \quad \text { lack of financial standing to perform the contract; } \\
\text { - lack of legal capacity to perform the contract; } \\
\text { - } \quad \text { bankruptcy or similar; } \\
\text { - } \quad \text { conviction of the firm of a criminal offence concerning } \\
\text { - } \quad \text { grofessional conduct; } \\
\text { - } \quad \text { failure to fulfil certain tax and social security obligations, or } \\
\text { - } \quad \text { serious misrepresentation in providing information on } \\
\text { - } \text { matters relating to the provider's exclusion or selection. } \\
\text { discriminate on grounds of nationality. } \\
\text { Only certain evidence explicitly referred to in the directives may } \\
\text { be demanded as proof of technical standing; other evidence cannot } \\
\text { be required. } \\
\text { Providers may offer any reasonable evidence to prove financial } \\
\text { standing. } \\
\text { In open procedures exclusion can take place only once bids have } \\
\text { been submitted (prequalification is not permitted). }\end{array}$ & $\begin{array}{l}\text { Exclusion is permitted on the basis of any } \\
\text { criteria which are "objective". This includes, } \\
\text { at least, all the criteria permitted under the } \\
\text { other directives: see previous column. } \\
\text { Criteria must not discriminate on grounds of } \\
\text { nationality. } \\
\text { Any reasonable evidence of financial and } \\
\text { technical standing may be demanded. } \\
\text { In open procedures exclusion can take place } \\
\text { only once bids have been submitted } \\
\text { (prequalification is not permitted). }\end{array}$ & 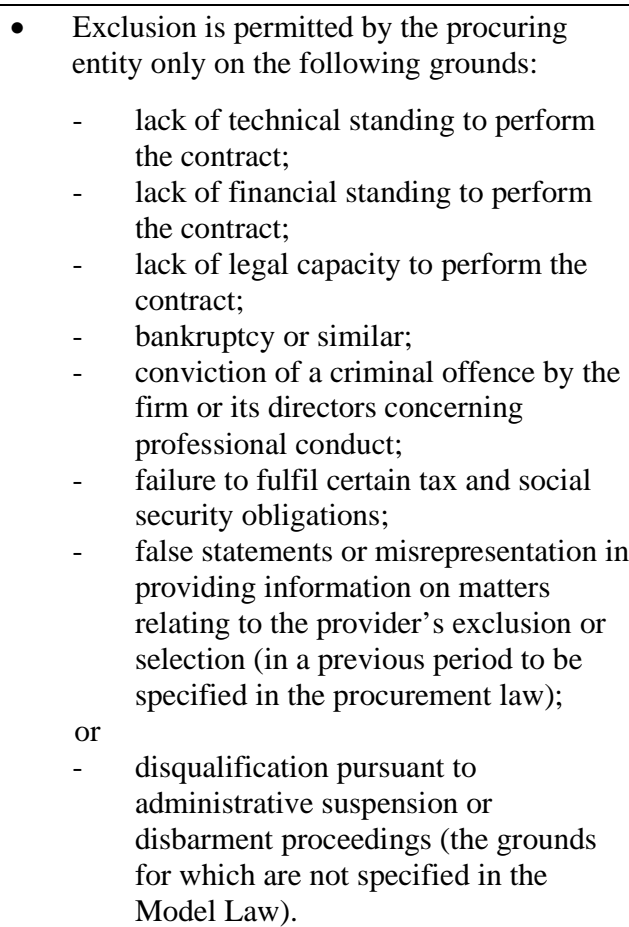 \\
\hline
\end{tabular}


CCNM/SIGMA/PUMA(2000)32

\begin{tabular}{|c|c|c|c|}
\hline & \multirow{2}{*}{ EC Directives 92/50, 93/36 and 93/37 } & \\
\hline & & EC Directive 93/38 & UNCITRAL Model Law \\
\hline & & & $\begin{array}{l}\text { Grounds for exclusion must be objectively } \\
\text { justifiable and must not discriminate on } \\
\text { grounds of nationality. } \\
\text { Procuring entity may generally demand any } \\
\text { evidence it deems useful to determine } \\
\text { financial and technical standing, and to } \\
\text { assess other grounds for disqualification. } \\
\text { There is an obligation to exclude any } \\
\text { provider giving false information. } \\
\text { (Exclusion is discretionary if the information } \\
\text { is merely in accurate or incomplete.). } \\
\text { In (open) tendering procedures exclusion } \\
\text { can take place prior to submission of bids } \\
\text { (i.e. prequalification is permitted). }\end{array}$ \\
\hline $\begin{array}{l}\text { Use of approved lists } \\
\text { (qualification lists). }\end{array}$ & $\begin{array}{l}\text { - Providers may not be required to register on lists as a condition of } \\
\text { participation. }\end{array}$ & $\begin{array}{l}\text { - Providers may be required to register on lists } \\
\text { as a condition of participation, where the list } \\
\text { is run in accordance with rules laid down in } \\
\text { the directive. } \\
\text { Advertisement of a list is sufficient to serve } \\
\text { as advertisement of contracts covered by the } \\
\text { list, provided that: } \\
\text { - Participation is restricted to those on } \\
\text { the list and } \\
\text { the list is advertised each year (or lasts } \\
\text { for less than } 3 \text { years). }\end{array}$ & $\begin{array}{l}\text { Does not deal with registration on lists as a } \\
\text { condition of participation. }\end{array}$ \\
\hline $\begin{array}{l}\text { Selecting bidders from } \\
\text { amongst qualified } \\
\text { providers } \\
\text { (shortlisting) }\end{array}$ & $\begin{array}{l}\text { - Shortlisting is permitted in restricted procedures (provided } \\
\text { number/range stated in advance) and negotiated procedures. It is } \\
\text { not relevant for open procedures. } \\
\text { - Number invited must be: } \\
\text { - For restricted procedures, between } 5 \text { and } 20 \text { and sufficient to } \\
\text { ensure genuine competition; } \\
\text { - for negotiated procedures, normally at least } 3 \text {. } \\
\text { - The only shortlisting criteria are the permitted grounds for } \\
\text { exclusion (e.g. the relative technical skills/experience or financial } \\
\text { position of firms). }\end{array}$ & $\begin{array}{l}\text { Shortlisting is permitted in restricted and } \\
\text { negotiated procedures but is not relevant for } \\
\text { open procedures. } \\
\text { - Number invited in restricted and negotiated } \\
\text { procedures must ensure adequate } \\
\text { competition. } \\
\text { - Any "objective" criteria can be used. }\end{array}$ & $\begin{array}{l}\text { Shortlisting is permitted for all procedures } \\
\text { except: } \\
\text { - } \quad \text { (open) tendering; } \\
\text { - open version of the principal method } \\
\text { for procurement of services; } \\
\text { - } \quad \text { restricted tendering where this is } \\
\text { chosen under Article } 20 \text { (a) (limited } \\
\text { number of providers available), when } \\
\text { all possible providers must be invited; } \\
\text { "direct solicitation" version of the } \\
\text { principal method for procurement of } \\
\text { services, where this is chosen under }\end{array}$ \\
\hline
\end{tabular}




\begin{tabular}{|c|c|c|c|}
\hline & EC Directives 92/50, 93/36 and 93/37 & EC Directive 93/38 & UNCITRAL Model Law \\
\hline & & & $\begin{array}{l}\text { Article 37(3)(a) (limited number of } \\
\text { providers), when all possible providers } \\
\text { must be invited; } \\
\text { two stage tendering. } \\
\text { - Number invited must be: } \\
\text { - } \quad \text { for restricted tendering, a sufficient } \\
\text { number to ensure effective competition; } \\
\text { for "direct solicitation" version of } \\
\text { principle method for procurement of } \\
\text { services, a sufficient number to ensure } \\
\text { effective competition; } \\
\text { for request for proposals, as many as } \\
\text { possible and normally at least 3; } \\
\text { for competitive negotiations, a } \\
\text { sufficient number to ensure effective } \\
\text { competition; } \\
\text { for request for quotations, as many as } \\
\text { practicable, but at least } 3 \text {. } \\
\text { For restricted tendering selection must } \\
\text { be done in a non-discriminatory } \\
\text { manner; for other procedures no } \\
\text { explicit criteria given. }\end{array}$ \\
\hline $\begin{array}{l}\text { Clarification and } \\
\text { modification of } \\
\text { solicitation documents } \\
\text { Non-responsive } \\
\text { tenders }\end{array}$ & $\begin{array}{l}\text { - } \quad \text { Tenders must be rejected where there are material deviations from } \\
\text { requirements. } \\
\text { - } \quad \text { Those with minor deviations may be rejected. }\end{array}$ & $\begin{array}{l}\text { - Tenders must be rejected where there are } \\
\text { material deviations from requirements. } \\
\text { Those with minor deviations may be } \\
\text { rejected. }\end{array}$ & $\begin{array}{l}\text { - Tenders must be rejected where there are } \\
\text { material deviations from requirements. } \\
\text { Those with minor deviations may be } \\
\text { rejected. }\end{array}$ \\
\hline $\begin{array}{l}\text { Discussions and } \\
\text { amendments of } \\
\text { tenders/proposals } \\
\text { after submission }\end{array}$ & $\begin{array}{l}\text { - In open and restricted procedures, clarification is permitted but } \\
\text { change to substance of bids is not allowed. } \\
\text { - In negotiated procedures discussions and amendments are } \\
\text { allowed, subject to the principle of equal treatment. }\end{array}$ & $\begin{array}{l}\text { In open and restricted procedures, } \\
\text { clarification is permitted but change to } \\
\text { substance of bids is not allowed. } \\
\text { In negotiated procedures discussions and } \\
\text { amendments are allowed, subject to the } \\
\text { principle of equal treatment. }\end{array}$ & $\begin{array}{l}\text { a. Goods and construction } \\
\text { Open and restricted tendering procedures: } \\
\text { clarification is permitted but change to } \\
\text { substance of bids is not allowed. } \\
\text { Two stage tendering: allows initial tendering } \\
\text { stage after which there may be negotiations } \\
\text { on tenders and revisions to those tenders. } \\
\text { Following the final tendering stage } \\
\text { clarification is permitted but change to } \\
\text { substance of bids is not allowed. }\end{array}$ \\
\hline
\end{tabular}


CCNM/SIGMA/PUMA(2000)32

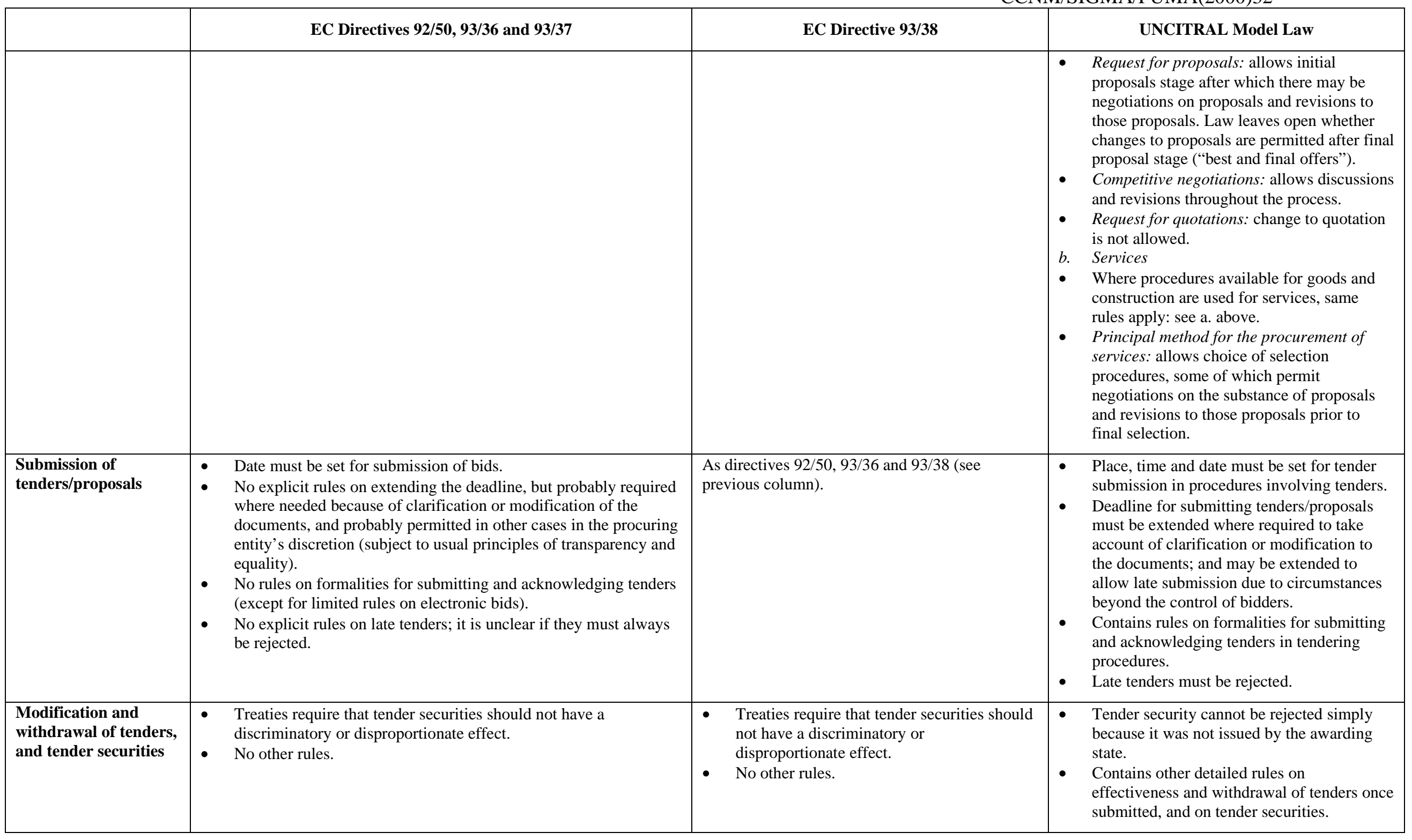




\begin{tabular}{|c|c|c|c|}
\hline & EC Directives 92/50, 93/36 and 93/37 & EC Directive 93/38 & UNCITRAL Model Law \\
\hline Opening of tenders & $\begin{array}{l}\text { No explicit rules, but general principles of equality and transparency } \\
\text { apply. The latter might require public opening/right of participants to } \\
\text { attend in tendering procedures, but this is not clear. }\end{array}$ & $\begin{array}{l}\text { No explicit rules, but general principles of } \\
\text { equality and transparency apply. The latter might } \\
\text { require public opening or right of participants to } \\
\text { attend in tendering procedures, but this is not } \\
\text { clear. }\end{array}$ & $\begin{array}{l}\text { - Tenders must be opened in accordance with } \\
\text { previously stated procedure and participants } \\
\text { must be permitted to attend. } \\
\text { Details of bidders and price must be } \\
\text { announced, communicated to participants } \\
\text { who are not present, and entered } \\
\text { immediately in the records. }\end{array}$ \\
\hline $\begin{array}{l}\text { Criteria for selecting } \\
\text { between } \\
\text { tenders/proposals }\end{array}$ & $\begin{array}{l}\text { - Lowest price } \text { or most economically advantageous tender. } \\
\text { Any criteria can be used to assess economic advantage, provided } \\
\text { that they relate to the procurement in question, and are concerned } \\
\text { with the delivery of the goods/construction/services. Industrial and } \\
\text { social development criteria are not permitted. } \\
\text { - Criteria other than price must be notified to bidders in advance. } \\
\text { - Criteria must be stated in order of preference where possible, but } \\
\text { need not be expressed in monetary terms or given a relative } \\
\text { weight. }\end{array}$ & $\begin{array}{l}\text { - Lowest price or most economically } \\
\text { advantageous tender, as notified to bidders. } \\
\text { Any criteria can be used to assess economic } \\
\text { advantage, provided that they relate to the } \\
\text { procurement in question, and are concerned } \\
\text { with the delivery of the goods/construction/ } \\
\text { services. Industrial and social development } \\
\text { criteria are not permitted, except for limited } \\
\text { provisions on preferences for "EU" goods. } \\
\text { Criteria for assessing the most advantageous } \\
\text { tender must be notified to bidders in } \\
\text { advance. } \\
\text { Criteria must be stated in order of preference } \\
\text { where possible, but need not be expressed in } \\
\text { monetary terms or given a relative weight. }\end{array}$ & $\begin{array}{l}\text { a. Goods and construction } \\
\text { All types of tendering procedures: } \\
\text { - Lowest price or lowest evaluated tender, as } \\
\text { notified to bidders. } \\
\text { - Criteria for determining the lowest evaluated } \\
\text { tender are limited to price; operation, } \\
\text { maintenance and repair costs; } \\
\text { delivery/completion time; functional } \\
\text { characteristics; terms of payment and } \\
\text { guarantees; any preferences to be given for } \\
\text { industrial development objectives or for } \\
\text { domestic industry; and defence/security } \\
\text { considerations. } \\
\text { Criteria for assessing the lowest evaluated } \\
\text { tender must be notified to bidders in } \\
\text { advance. } \\
\text { To the extent practicable, criteria must be } \\
\text { objective and quantifiable, and expressed in } \\
\text { monetary terms or given a relative weight } \\
\text { Request for proposals: } \\
\text { - Criteria for evaluating proposals are limited } \\
\text { to the relative managerial and technical } \\
\text { competence of the provider; the } \\
\text { effectiveness of the proposal; and price plus } \\
\text { cost of operation, maintenance and repair. } \\
\text { Criteria for evaluation must be notified to } \\
\text { bidders in advance. } \\
\text { To the extent practicable criteria must be } \\
\text { expressed in monetary terms; they must be } \\
\text { given a relative weight; and the way in }\end{array}$ \\
\hline
\end{tabular}


CCNM/SIGMA/PUMA(2000)32

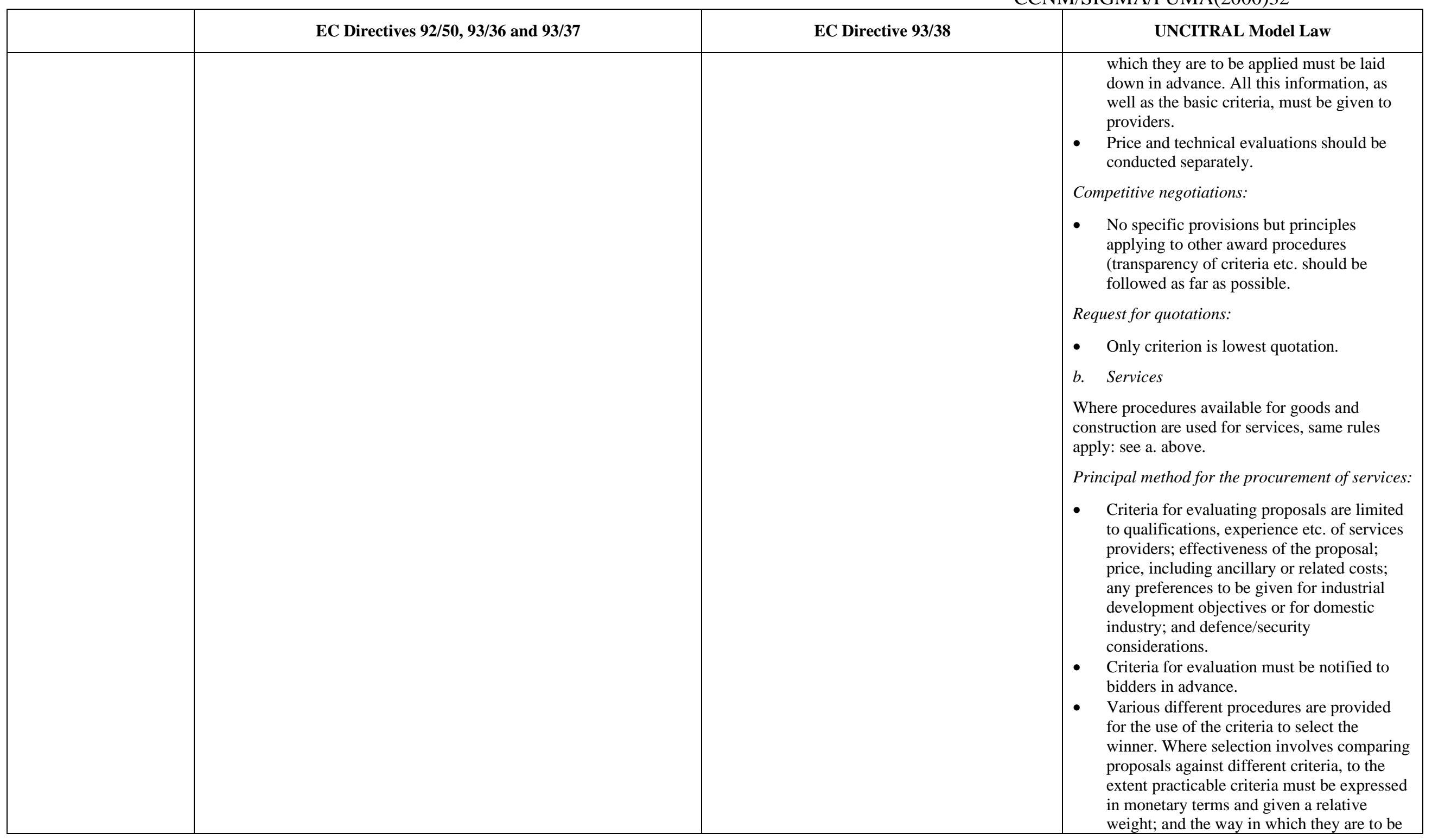




\begin{tabular}{|c|c|c|c|}
\hline & EC Directives 92/50, 93/36 and 93/37 & EC Directive 93/38 & UNCITRAL Model Law \\
\hline & & & $\begin{array}{l}\text { applied must be laid down in advance. All } \\
\text { this information, as well as the basic criteria, } \\
\text { must be given to providers. }\end{array}$ \\
\hline Rejection of all offers & $\begin{array}{l}\text { - } \\
\text { - } \quad \text { Notice that all offers are rejected must be given promptly to all } \\
\text { participants (in writing if requested). } \\
\text { - The reason for rejecting all offers must be communicated to } \\
\text { participants promptly (in writing if requested). } \\
\text { Legal liability of the procuring entity for rejecting all offers } \\
\text { depends on the law of the awarding state. }\end{array}$ & $\begin{array}{l}\text { Procuring entity may reject all offers in its } \\
\text { discretion. } \\
\text { Legal liability of the procuring entity for } \\
\text { rejecting all offers depends on the law of the } \\
\text { awarding state. }\end{array}$ & $\begin{array}{l}\text { - } \begin{array}{l}\text { Procuring entity may reject all offers in its } \\
\text { discretion. }\end{array} \\
\text { - } \quad \text { Notice that all offers are rejected must be } \\
\text { given promptly to all participants. } \\
\text { The reason for rejecting all offers must be } \\
\text { communication on request, but the procuring } \\
\text { entity need not justify its grounds. } \\
\text { Procuring entity is under no legal liability } \\
\text { for rejecting all offers. }\end{array}$ \\
\hline $\begin{array}{l}\text { Time limits for } \\
\text { procedures. }\end{array}$ & $\begin{array}{l}\text { - Minimum time limits set for some processes to ensure time for all } \\
\text { providers, including foreign ones, to respond. These include: } \\
\text { - For expressions of interest in restricted and negotiated } \\
\text { procedures normally } 37 \text { days from dispatch of the notice, but } \\
\text { may be reduced as necessary down to } 15 \text { days in urgent } \\
\text { cases. } \\
\text { - For tenders normally } 52 \text { days from invitations in open } \\
\text { procedures (or shorter where contract has been referred to in } \\
\text { a general advance notice); and normally } 40 \text { in restricted or } \\
\text { negotiated procedures (or down to } 10 \text { in urgent cases). }\end{array}$ & $\begin{array}{l}\text { - Minimum time limits set for some processes } \\
\text { to ensure time for all providers, including } \\
\text { foreign ones, to respond. These include: } \\
\text { - } \quad \text { For expressions of interest in restricted } \\
\text { or negotiated procedures normally } 37 \\
\text { days from dispatch of relevant notice or } \\
\text { invitation, but may be reduced down to } \\
22 \text { days where warranted by urgency or } \\
\text { other circumstances. } \\
\text { - For tenders, normally } 52 \text { days from } \\
\text { invitations in open procedures (or } \\
\text { shorter where contract has been referred } \\
\text { to in a general advance notice). In } \\
\text { restricted or negotiated procedures to be } \\
\text { fixed by agreement; in absence of } \\
\text { agreement, normally } 24 \text { days but may } \\
\text { be reduced where warranted by urgency } \\
\text { or other circumstances. }\end{array}$ & $\begin{array}{l}\text { No specified time limits; to be set by } \\
\text { regulating state or procuring entity. }\end{array}$ \\
\hline $\begin{array}{l}\text { Technical } \\
\text { specifications }\end{array}$ & $\begin{array}{l}\text { - Under the Treaties, specifications must not exclude products or } \\
\text { services that can meet the entity's functional requirements. Note } \\
\text { that requirement for products to comply with standards of national } \\
\text { standardising bodies will infringe this requirement unless } \\
\text { equivalents are also accepted. } \\
\text { European specifications must be used where these exist, subject to } \\
\text { certain exceptions. (Note: it is unclear whether this is subject to }\end{array}$ & $\begin{array}{l}\text { - Under the Treaties, specifications must not } \\
\text { exclude products or services that can meet } \\
\text { the entity's functional requirements. Note } \\
\text { that requirement for products to comply with } \\
\text { standards of national standardising bodies } \\
\text { will infringe this requirement unless } \\
\text { equivalents are also accepted. }\end{array}$ & $\begin{array}{l}\text { Specifications must not create obstacles to } \\
\text { participation, whether based on nationality } \\
\text { or other grounds. Note that requirement for } \\
\text { products to comply with standards of } \\
\text { national standardising bodies will infringe } \\
\text { this requirement unless equivalents are also } \\
\text { accepted. (It is unclear whether exclusion of }\end{array}$ \\
\hline
\end{tabular}




\begin{tabular}{|c|c|c|c|}
\hline & & & \\
\hline & EC Directives 92/50, 93/36 and 93/37 & EC Directive 93/38 & UNCITRAL Model Law \\
\hline & $\begin{array}{l}\text { the rule above, so that entities must also accept alternatives } \\
\text { meeting their functional requirements.) Because of the GPA } \\
\text { international standards must also be used for most contracts where } \\
\text { available, subject to exceptions. Where no European or } \\
\text { international standards exist, provision is made for using certain } \\
\text { other standards, where available. } \\
\text { In all cases there must also generally be no reference to goods of a } \\
\text { specific make, source or process (including patents, trademarks } \\
\text { etc.) unless: } \\
\text { - this is indispensable for the contract or } \\
\text { - this is the only way to describe requirements in which case } \\
\text { "or equivalent" must be added and equivalents accepted. }\end{array}$ & 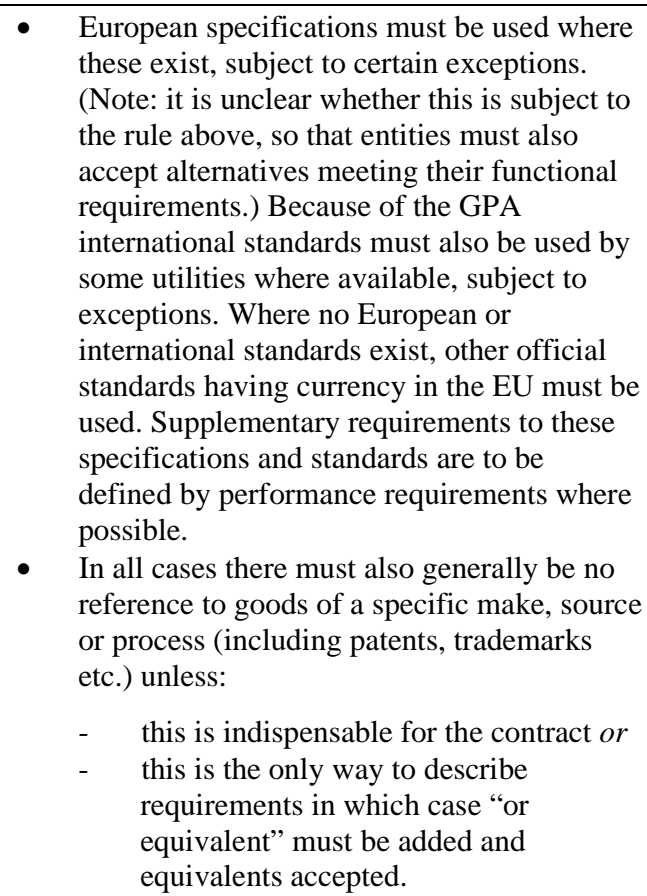 & $\begin{array}{l}\text { any product or service meeting the entity's } \\
\text { functional requirements would also infringe } \\
\text { this provision.) } \\
\text { - No requirement to use any particular type of } \\
\text { national, regional or international standards. } \\
\text { In all cases there must generally be no } \\
\text { reference to goods of a specific source, } \\
\text { process, patent, trademark etc. unless this is } \\
\text { the only way to describe requirements in } \\
\text { which case "or equivalent" must be added } \\
\text { and equivalents accepted. }\end{array}$ \\
\hline $\begin{array}{l}\text { Record of } \\
\text { procurement } \\
\text { proceedings }\end{array}$ & $\begin{array}{l}\text { Requirement to keep written record of all award procedures, containing } \\
\text { specified information. This must be made available to the European } \\
\text { Commission, either on request or (in certain cases) automatically. }\end{array}$ & $\begin{array}{l}\text { Requirement to keep written record of all award } \\
\text { procedures, containing specified information. } \\
\text { This must be made available to the European } \\
\text { Commission, either on request or (in certain } \\
\text { cases) automatically. }\end{array}$ & $\begin{array}{l}\text { Requirement to keep a record of all award } \\
\text { procedures, containing specified information, } \\
\text { some of which must be made available to any } \\
\text { person on request. }\end{array}$ \\
\hline $\begin{array}{l}\text { Notices concerning the } \\
\text { award of a contract }\end{array}$ & $\begin{array}{l}\text { Notice with certain details of award to be sent within } 48 \text { days for } \\
\text { publication by the Official Journal. (Like most obligations affects } \\
\text { above-threshold contracts only.) }\end{array}$ & $\begin{array}{l}\text { Notice with certain details of award to be sent } \\
\text { within } 2 \text { months for publication by the Official } \\
\text { Journal. (Like most obligations affects } \\
\text { above-threshold contracts only). }\end{array}$ & $\begin{array}{l}\text { Notice of award to be published "promptly", } \\
\text { except for contracts below a threshold specified } \\
\text { in the procurement legislation. }\end{array}$ \\
\hline $\begin{array}{l}\text { Information to } \\
\text { participants }\end{array}$ & $\begin{array}{l}\text { Participants must be informed promptly of award decisions (in } \\
\text { writing if requested). In states where damages is the only available } \\
\text { remedy after conclusion of a contract, the contract must not be } \\
\text { concluded until after a reasonable period from the notification of } \\
\text { award. }\end{array}$ & $\begin{array}{l}\text { - In certain utility sectors only, participants } \\
\text { must be informed promptly of award } \\
\text { decisions (in writing if requested). In all } \\
\text { utility sectors, in states where damages is the } \\
\text { only available remedy after conclusion of a }\end{array}$ & $\begin{array}{l}\text { - The winner must be informed promptly of } \\
\text { the award decision. Automatic notice to } \\
\text { other participants is required only once the } \\
\text { contract has been concluded and appropriate } \\
\text { security given. }\end{array}$ \\
\hline
\end{tabular}




\begin{tabular}{|c|c|c|c|}
\hline & EC Directives 92/50, 93/36 and 93/37 & EC Directive 93/38 & UNCITRAL Model Law \\
\hline & $\begin{array}{l}\text { Participants must be supplied with reasons for certain decisions, } \\
\text { within } 15 \text { days of a request (subject to exceptions for } \\
\text { confidentiality etc.). }\end{array}$ & $\begin{array}{l}\text { contract, the contract must not be concluded } \\
\text { until after a reasonable period from the } \\
\text { notification of award. } \\
\text { In certain utility sectors only, participants } \\
\text { must be supplied with reasons for certain } \\
\text { decisions, within fifteen days of a request } \\
\text { (subject to exceptions for confidentiality } \\
\text { etc.). }\end{array}$ & $\begin{array}{l}\text { Participants must be supplied with reasons } \\
\text { for certain decisions, as contained in the } \\
\text { procurement record, on request (subject to } \\
\text { exceptions for confidentiality etc.). No time } \\
\text { limit for provision of the information is } \\
\text { specified. Applies only after acceptance of } \\
\text { the offer or termination of procedure. }\end{array}$ \\
\hline $\begin{array}{l}\text { Review and } \\
\text { enforcement by } \\
\text { aggrieved providers }\end{array}$ & $\begin{array}{l}\text { Providers must be given a rapid and effective right of review } \\
\text { before, or appeal to, an independent, judicial-type national review } \\
\text { body. This must be able to make binding and enforceable } \\
\text { decisions on whether there has been compliance with EU law. } \\
\text { The following must all be available remedies from the review } \\
\text { body before the contract is concluded: } \\
\text { - } \quad \text { Suspension of the procedure until the trial (but this may be } \\
\text { refused for reasons of public interest); } \\
\text { - } \quad \text { set aside of unlawful decisions; and } \\
\text { - } \quad \text { damages (including for lost profits). } \\
\text { Remedies may be limited to damages once the contract has been } \\
\text { concluded; but in this case providers must be notified of the award } \\
\text { decision a reasonable time before the contract is concluded. } \\
\text { States may also maintain systems of administrative complaint or } \\
\text { review if they wish. } \\
\text { Providers can also complain to the European Commission, which } \\
\text { may take action and ultimately bring proceedings before the ECJ. }\end{array}$ & $\begin{array}{l}\text { Right of review and enforcement is similar to the } \\
\text { other directives (see previous column), except } \\
\text { that: } \\
\text { - dissuasive financial sanctions only may be } \\
\text { used where the regulating state does not } \\
\text { want to allow the review body to award set } \\
\text { aside or suspension remedies, } \\
\text { an EU-level mediation procedure (referred } \\
\text { to as "conciliation") is also available. }\end{array}$ & $\begin{array}{l}\text { - There is no suggested requirement for an } \\
\text { effective right of review before, or appeal to, } \\
\text { an independent, judicial-type national } \\
\text { review body, although it is acknowledged } \\
\text { that states may wish to provide for this. } \\
\text { A formal system of administrative review } \\
\text { for complaints by providers is suggested, but } \\
\text { this need not be independent, and its rulings } \\
\text { need not be binding and enforceable. } \\
\text { Suggested remedies or recommendations } \\
\text { are: } \\
\text { - automatic suspension of the procedure } \\
\text { (but this may be overridden for reasons } \\
\text { of public interest); } \\
\text { set aside of unlawful decisions and } \\
\text { similar measures, or direct correction of } \\
\text { the unlawful decision; and } \\
\text { damages (including for lost profits or } \\
\text { limited to costs, according to the choice } \\
\text { of the regulating state). } \\
\text { Other forms of enforcement are left to the } \\
\text { discretion of the regulating state. }\end{array}$ \\
\hline Collection of statistics & $\begin{array}{l}\text { States must provide the European Commission with specified statistics } \\
\text { on procurement. }\end{array}$ & $\begin{array}{l}\text { States must provide the European Commission } \\
\text { with specified statistics on procurement. }\end{array}$ & $\begin{array}{l}\text { No provisions on collection or submission of } \\
\text { statistics. }\end{array}$ \\
\hline
\end{tabular}

